\title{
AN ENGLISH SPEAKING TRAINING FOR THE DRAGON FRUIT PLANTATION WORKERS IN REMPANG ISLAND BATAM: AGRO-TOURISM BASE
}

\author{
Ambalegin Ambalegin \\ Universitas Putera Batam (UPB), Batam, Indonesia \\ e-mail: Ambalegin@puterabatam.ac.id \\ Tomi Arianto \\ Universitas Putera Batam (UPB), Batam, Indonesia \\ e-mail:Tomi.Arianto@puterabatam.ac.id \\ Nurma Dhona Handayani \\ Universitas Putera Batam (UPB), Batam, Indonesia \\ e-mail: Nurma@puterabatam.ac.id \\ Zia Hisni Mubarak \\ Universitas Putera Batam (UPB), Batam, Indonesia \\ e-mail: Zia.Hisni@puterabatam.ac.id
}

\begin{abstract}
Batam is the third most visited city of foreign tourists due to the strategic location that closes to Singapore and Malaysia. It becomes a distinct advantage with the number of tourists visiting. In addition to marine tourism and shopping tourism, Batam has agrotourism in the islands around Batam Island. Cafe Zore in Rempang Island's dragon fruit plantation is often visited by domestic and foreign tourists. Foreign tourists often experience difficulties in communicating with English because the employees could not speak English. It is aimed to develop employees' English skills through methods of community education and training with lecturing, discussion and demonstration techniques. The result of this training was the improvement of the English spoken ability. To sum up this PkM activity is that English communication skills are very important to welcome foreign tourists visiting and support the government to develop tourism in Batam.
\end{abstract}

Keywords - agrotourism, Infromal English Conversation, dragon fruit plantation the workers

\section{PENDAHULUAN}

Pemerintah Kota Batam (6/12/2016) memperoleh penghargaan pariwisata yaitu indeks pariwisata tertinggi di Indonesia. Sektor pariwisata yang sehat akan mendukung tunbuhnya ekonomi daerah maupun nasional. Hal ini dipaparkan oleh M.Rudi, walikota Batam di Jakarta (6/12/2016) Batam memiliki jumlah kunjungan wisatawan terbanyak setelah Bali dan Jakarta. Pencapaian pengembangan pariwisata yang tepat harus melibatkan seluruh lapisan masyarakat untuk meningkatkan kesejahteraan masyarakat di daerah pariwisata (Nugraha et al., 2019). Suksesnya pariwisata di Batam melibatkan seluruh golongan masyarakat 
seperti akademisi, pelaku bisnis, komunitas, pemerintah, dan media. Pulau Batam berlokasi di provinsi Kepulauan Riau menjadi destinasi turis asing karena Batam bertetangga dengan negara Singapura dan Malaysia sehingga menjadi keuntungan tersendiri bagi Pulau Batam.

Turis mancanegara berkunjung ke Batam melalui jalur udara (Bandara Hang Nadim Batam) dan laut (Pelabuhan Internasional Batam Centre, Harbour Bay, Nongsa Pura, dan Sekupang). Evyanto, W., \& Mubarak, Z. H. (2020) mengatakan bahwa Batam sebagai pusat destinasi yang menarik bagi para turis mancanegara untuk berwisata. Mereka datang ke Batam tidak hanya menikmati keindahan pantai dan wisata belanja di beberapa tempat di Batam seperti Nagoya Winsor, atau Jodoh tetapi Batam juga memiliki wisata berbasis perkebunan. Lokasi wisata berbasis perkebunan berada di sekitar pulau-pulau di Batam seperti Rempang dan Galang. Pulau-pulau tersebut dimanfaatkan sebagai daerah perkebunan yang ditanami dengan tanaman tropik yang tahan terhadap cuaca panas sepanjang hari seperti buah naga. Perkebunan buah naga adalah salah satunya yang dibudidayakan di Pulau Rempang. Pengelola mengembangkan perkebunan ini untuk menarik kedatangan wisatawan dalam dan luar negeri.

Kawasan pertanian yang menjadi area agrowisata dapat meningkatkan kedatangan wisatawan dalam dan luar negeri sehingga memberikan kontribusi peningkatan pendapatan masyarakat (Budiarti et al., 2013). Sejalan dengan itu diperlukan pengembangan SDM agar masyarakat mengelola dan mengembangkan daerah wisata, dan meningkatkan kualitas masyarakat untuk pengelolaan kegiatan agrowisata (Andidi, 2014).

Perkebunan buah naga adalah tanaman khas yang terdapat di pulau Rempang. Infrastruktur sudah sangat mendukung apalagi dekat dengan ikon Pulau Batam yaitu Jembatan Barelang membuat perkebunan tersebut mudah dijangkau. Dari hasil observasi banyak wisatawan asing yang datang menikmati buah dan melihat perkebunannya. Kafe Zore adalah kafe yang menyediakan jus buah naga dengan pemandangan perkebunan buah naga. Terkadang pengunjung diajak untuk berkeliling di sekitar perkebunan. Banyak yang ingin ditanyakan oleh pengunjung seperti pengunjung dari Jerman tetapi pegawai perkebunan buah naga tidak mampu berkomunikasi dalam Bahasa Inggris ketika berbicara dengan wisatawan asing.
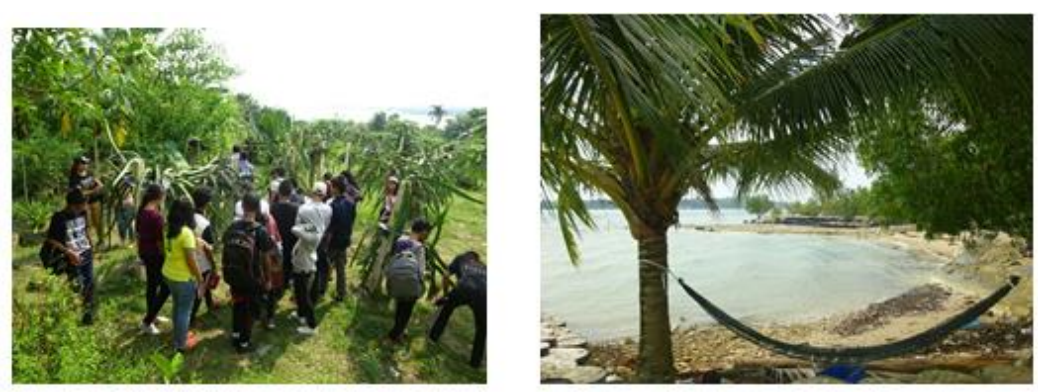

Gambar 1. Keindahan Perkebunan Buah Naga

Di era globalisasi ini, untuk bersaing dalam dunia usaha dibutuhkan kemampuan berbahasa Inggris. Crystal (2003) menginformasikan bahwa Bahasa Inggris berperan penting dalam politik, bisnis, hiburan, hubungan internasional, media massa, perjalanan internasional, keamanan internasional, pendidikan, dan komunikasi. Kachru et al. (2006) mengatakan mampu berbahasa Inggris 
membuka gerbang menuju bisnis international, teknologi, pengetahuan, dan perjalanan,

Dari hasil kegiatan wawancara dan observasi, pemilik perkebunan adalah pribadi bukan masyarakat setempat tetapi pegawai kafe dan perkebunan buah naga adalah masyarakat setempat yang memiliki latar belakang pendidikan yang rendah menjadikan mereka memiliki kemampuan komunikasi yang rendah serta kemampuan Bahasa Inggris yang rendah. Pegawai kafe dan perkebunan buah naga mengharapkan kegiatan pembelajaran Bahasa Inggris karena tidak lancar berbahasa Inggris ketika berhadapan dengan wisatawan mancanegara. Ada beberapa alasan yang memengaruhi mereka untuk berbahasa Inggris. Seperti yang disebutkan Ambalegin et al. (2017), kendala dari orang dewasa enggan berbahasa Inggris karena tidak percaya diri, malu, takut salah, dan kurangnya kosakata bahasa Inggris. Pegawai kafe dan perkebunan buah naga setuju bahwa mereka tidak mampu untuk menjawab karena tidak mengerti pada saat mendengar. Mereka sangat ingin belajar Bahasa Inggris diluar waktu jadwal kerja mereka.

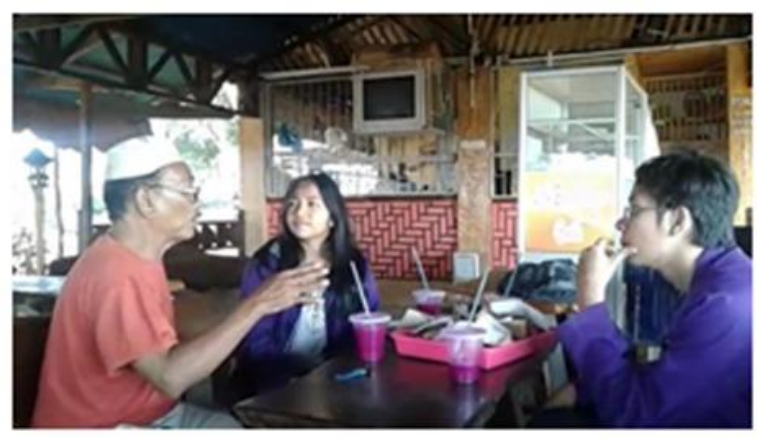

Gambar 2. Anggota Tim Pengabdi diskusi dengan peserta pengabdian

Bahasa Inggris adalah komunikasi dan kunci dari suksesnya acara ini seperti dikatakan pemilik kafe Zore. Di samping Bahasa Indonesia atau Melayu, Bahasa Inggris sebagai bahasa global akan dijadikan bahasa sehari-hari dalam melayani pengunjung dari luar negeri. Penggunaan Bahasa Inggris yang benar dan baik akan menjadi perhatian pengunjung sehingga pengunjung akan betah untuk berlama-lama menikmati keindahan perkebunan (Ambalegin et al., 2019). "Hampir semua pegawai pasif berbahasa Inggris," lanjut pemilik kafe ketika ditanya mengenai kemampuan berbahasa Inggris pegawai. Bahasa Inggris bukanlah bahasa sehari-hari yang digunakan oleh warga Pulau Batam maka sah saja jika mereka tidak bisa berbahasa Inggris tetapi mereka tidak buta dengan bahasa Inggris karena Bahasa Inggris adalah pelajaran wajib dalam kurikulum di SMP dan SMA. Dan pada artikel pengabdian Amna et al. (2021) dijelaskan bahwa pembelajaran Bahasa Inggris pada tingkat menengah sudah pada level English Proficiency yaitu menggunakan bentuk konteks iklan, pengumuman, bacaan hingga tenses.

Peserta bekerja setiap hari dari pagi hingga sore. Rutinitas sehari-hari yang melelahkan membuat mereka berisitirahat disaat selesai bekerja. Belajar merupakan hal yang melelahkan untuk mereka. Ini menjadi kendala bagi mereka untuk belajar menambah keterampilan diri seperti keterampilan berbahasa. Begitu juga jika belajar dengan mengeluarkan biaya, mereka tidak akan setuju karena pendapatan yang tidak mendukung untuk itu.

Berdasarkan permasalahan yang dihadapi pegawai kafe dan perkebunan buah naga, maka tim pengabdi melatih Bahasa Inggris pada kemampuan berkomunikasi (English-Spoken Skill). Pelatihan adalah kegiatan yang efektif 
untuk menumbuhkembangkan kepercayaan, peluang, dan kinerja warga minoritas dalam mengatasi masalah yang ada di lingkungannya, dan untuk itu, dilakukan pelatihan berkomunikasi dalam Bahasa Inggris. Keterampilan dasar berkomunikasi yang dimiliki adalah tentang uang, liburan, cuaca, dan pekerjaan, sementara fungsi-fungsi kebahasaan yang digunakan antara lain; salam, memberi informasi, memberi arah, bertanya dan menjawab, mengklarifikasi, berterima kasih, memaafkan, memesan, menawar, menyarankan, dan membujuk.

Di tahun 2017, tim pengabdi telah melaksanakan pelatihan Bahasa Inggris bagi supir taksi di Pelabuhan Internasional Batam Centre. Artikel ini dipublikasikan di jurnal JPPM Universitas Muhammadiyah Purwokerto di bulan Maret 2020 (Ambalegin \& Suhardianto, 2020). Tujuan dari pengabdian ini adalah untuk mengenalkan kearifan lokal pulau Batam kepada wisatawan asing melalui penggunaan Bahasa Inggris. Sasaran supir taksi karena supir taksi sebagai garda terdepan pelayanan kepada wisatawan mancanegara. Hasil dari pengabdian tersebut menunjukkan peserta dapat berbahasa Inggris walaupun tidak fasih tetapi mereka mengetahui dasar-dasar berbahasa Inggris.

\section{METODE}

Kegiatan yang dilaksanakan dari tanggal 13, 15, dan 19 Februari 2018 menggunakan metode pendidikan masyarakat (ceramah) dan pelatihan dalam menyelesaikan permasalahan pegawai. Pelatihan Informal English Conversation ditunjukkan pada gambar berikut ini.

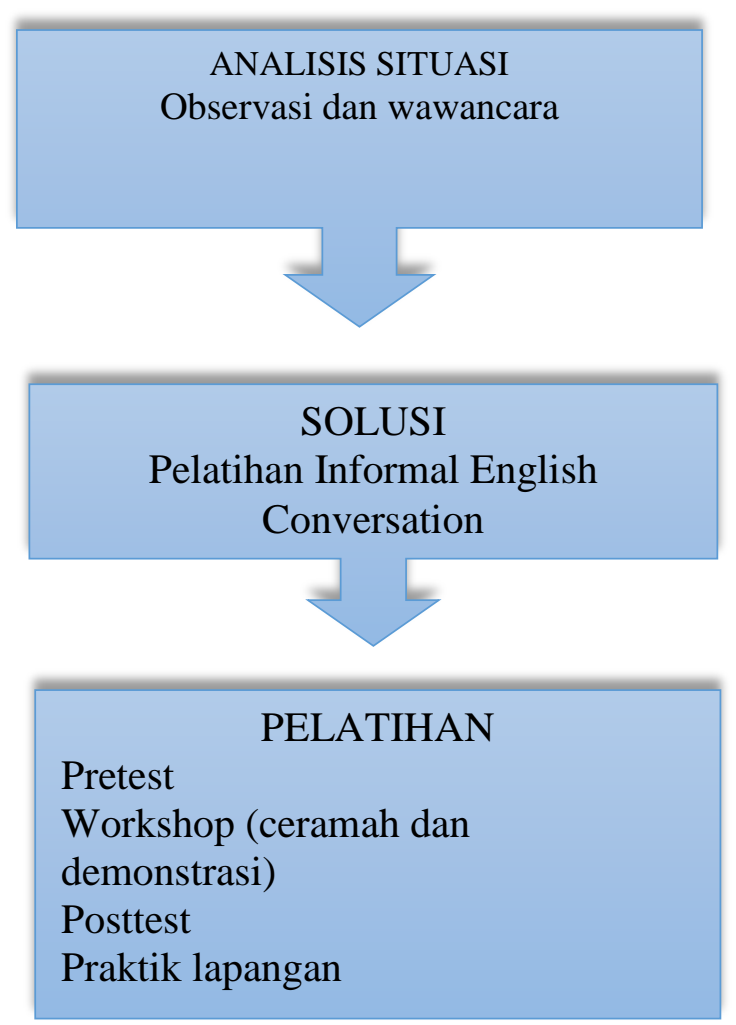

Gambar 3. Alur Kegiatan Pengabdian 
Analisis situasi bertujuan untuk menentukan metode, jenis pelatihan, materi pelatihan, dan waktu dan tempat kegiatan pengabdian. Dan target pelatihan adalah peserta mampu berkomunikasi dalam Bahasa Inggris.

Pelatihan diawali dengan latihan tertulis awal (pre-test) dan tanya-jawab lisan berbahasa Inggris untuk mengetahui kemampuan Bahasa Inggris peserta. Dengan metode workshop, pertemuan pertama diawali dengan ceramah dengan topik salam, memberi informasi, memberi arah, bertanya dan menjawab, mengklarifikasi. Melalui teknik student-center learning, peserta melakukan percakapan Bahasa Inggris dengan topik yang telah diberikan. Pada pertemuan kedua, topik yang diberikan adalah berterima kasih, memaafkan, memesan, menawar, menyarankan, dan membujuk. Peserta mempraktikkan materi ceramah dengan latihan percakapan antar teman. Pelatihan ini diberikan selama 2 jam pada setiap pelatihan.

Saat pelatihan, seorang pegawai dipilih untuk praktik berbahasa Inggris dengan pengunjung di kafe dan perkebunan. Pelatihan diakhiri dengan latihan tertulis (post-test) dan memberikan pendapat tentang kekurangan kegiatan pengabdian untuk memperbaiki kegiatan pengabdian selanjutnya. Pengabdian ditutup dengan membagi materi untuk pegawai dapat mempelajari materi secara mandiri.

\section{HASIL DAN PEMBAHASAN}

Mitra sasaran adalah pegawai Cafe Zore dan perkebunan buah naga Pulau Rempang, Batam. Peserta terdiri dari 15 pegawai. Dan peserta yang aktif berjumlah 11 dan selebihnya masih bekerja. Pelatihan diawali dengan latihan Bahasa Inggris tertulis, untuk mengetahui kemampuan peserta karena pemberian tes adalah prosedur untuk mengobservasi tingkah laku seseorang dan mendeskripsikannya secara sistematis dalam bentuk skala angka atau sistem kategori (Mustafidah \& Harjono, 2019).

Hasil pre-test menunjukkan rata-rata nilai pre-test adalah 38,18 dan hasil wawancara Bahasa Inggris dikelompokkan pada level rendah. Dan oleh karena hal itu, dilaksanakan pelatihan (workshop) melalui teknik ceramah dan demonstrasi. Materi ceramah sesuai dengan topik percakapan antara pegawai dan pengunjung yaitu uang, liburan, cuaca, dan pekerjaan, sementara fungsifungsi kebahasaan yang digunakan antara lain; salam, memberi informasi, memberi arah, bertanya dan menjawab, mengklarifikasi, berterima kasih, memaafkan, memesan, menawar, menyarankan, dan membujuk.

Latihan tertulis kedua dilaksanakan setelah kegiatan workshop. Rata-rata nilai post-test adalah 51,36 dengan rata-rata kenaikan adalah 13,18.

Tabel 1. Perbandingan Hasil Pre-Test dan Post-Test

\begin{tabular}{llcccc}
\hline No & Peserta & Umur & $\begin{array}{c}\text { Pre-test } \\
(\mathbf{0 - 1 0 0 )}\end{array}$ & $\begin{array}{c}\text { Post-test } \\
(\mathbf{0 - 1 0 0 )}\end{array}$ & $\begin{array}{c}\text { Persentase } \\
\text { Kenaikan }\end{array}$ \\
\hline 1 & Budi & 40 & 20 & 40 & 20 \\
2 & Robert & 28 & 50 & 60 & 10 \\
3 & Florens & 31 & 30 & 60 & 30 \\
4 & Ita & 25 & 25 & 50 & 25 \\
5 & Andi & 35 & 60 & 65 & 05 \\
6 & Toto & 50 & 10 & 30 & 20 \\
7 & Sugeng & 40 & 55 & 60 & 05 \\
8 & Leman & 45 & 25 & 40 & 15
\end{tabular}




\begin{tabular}{clllcc}
9 & Iwan & 41 & 10 & 20 & 10 \\
10 & Atho & 32 & 65 & 65 & 00 \\
11 & Ahmad & 20 & 70 & 75 & 05 \\
\hline Rata-rata kenaikan & & & 13,18 \\
\hline
\end{tabular}

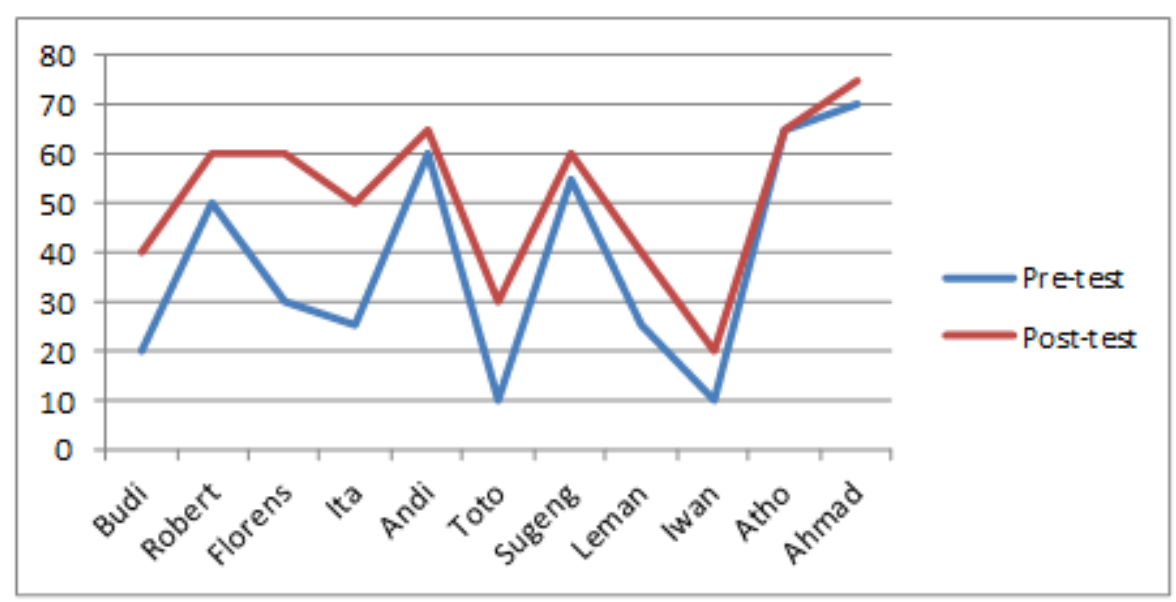

Gambar 4. Diagram kenaikan nilai pre-test dan post-test peserta pengabdian

Kesalahan soal umumnya pada pembuatan pertanyaan dan respon terhadap pertanyaan pelanggan. Dari hasil tanya-jawab lisan dalam Bahasa Inggris diketahui umumnya peserta salah dalam pengucapan dan pembentukan kalimat, dan minimnya kosa kata. Hal ini disebabkan peserta berkomunikasi dengan Bahasa Indonesia dan bahasa daerah. Permasalahan ini membuat tim pengabdi memberi pelatihan tambahan berupa pelatihan singkat English Pronunciation dan Grammar.

Pelatihan yang fokus pada kemampuan berkomunikasi Bahasa Inggris memberikan pengetahuan tentang cara berkomunikasi pegawai saat melayani pengunjung. Pelatihan ini dibantu oleh mahasiswa program studi Sastra Inggris untuk memberi pengalaman mahasiswa di lapangan.

Pelatihan dilaksanakan di basecamp di perkebunan buah naga Pulau Rempang, Batam tempat pegawai beristirahat. Alat tulis disediakan oleh tim pengabdi dan kudapan berupa gorengan disediakan karena peserta yang mengikuti pelatihan setelah selesai bekerja tetapi hal ini bukan merupakan kendala bagi tim pengabdi.

Setelah pegawai perkebunan selesai membersihkan area perkebunan, pelatihan dilaksanakan. Ada sebagian yang masih bekerja. Tim pengabdi memberikan materi tentang dialog dan kosakata bahasa Inggris seperi in the garden. Tim pengabdi melatih pengucapan dan pembentukan kalimat. Peserta bersemangat dalam pelatihan sehingga memotivasi tim pengabdi untuk melakukan pelatihan. Pelatihan yang diberikan yaitu pengucapan (pronunciation) seperti contoh kata yang sering diucapkan adalah: apologize, what can I do.., sorry, excuse me, dan thank you. Peserta masih kaku mengucapkan. Dengan pelatihan mendengar dan pelatihan yang berulang, peserta dapat mengucapkan dengan benar. Pada akhirnya satu per satu peserta diminta untuk membaca teks dialog. 


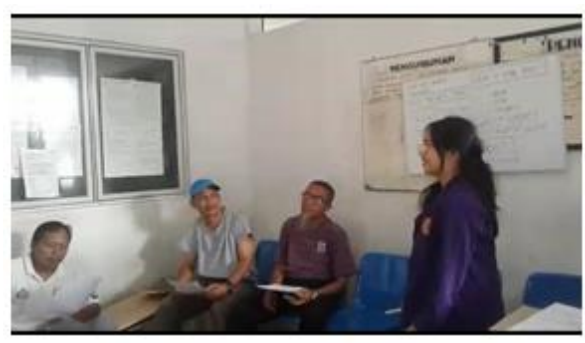

Gambar 5. Kegiatan Pelatihan oleh Mahasiswa-Mahasiswi Prodi Sastra Inggris, Universitas Putera Batam

Pada pembelajaran struktur (grammar), peserta kesulitan dalam membuat kalimat sesuai dengan waktu tertentu. Tim pengabdi melatih penggunaan verb be, is, am, are untuk mendeskripsikan benda, menunjukkan benda dan waktu, dan materi dalam bentuk positif, negatif, dan tanya. Peserta diminta mencontohkan kalimat dalam bentuk bentuk positif, negatif, dan tanya dengan verb be, is, am, are. Pemberian pelatihan penggunaan do, does, dan did untuk mendeskripsikan kalimat tanya. Tim pengabdi mengajarkan pembentukkan kalimat tanya $5-W h$ dan $1-H$ dan peserta diminta untuk membuat contoh kalimat tanya.

Pada pertemuan kedua, pembelajaran memperkenalkan kosakata seputar salam (vocabulary), pengucapan (pronunciation), struktur (grammar). Contoh kata yang sering diberikan seperti apologize, ashame, sorry, refuse, quite, dan lainnya. Pelatihan dilanjutkan pada materi yang lebih kompleks seperti expression of thanking, apologizing, dan persuading.

Pertemuan pertama dan kedua, menggunakan teknik student-center learning dengan mengajak peserta berlatih rasa percaya diri berbahasa Inggris bersama teman (in-paired practice). Inti dari komunikasi adalah mengembangkan relasi pertemanan dan membangun kepercayaan antar teman dalam organisasi melalui informasi yang diberikan (Nugraha et al., 2019). Peserta cukup senang walaupun dengan keadaan seadanya karena peserta tahu akan pentingnya pelatihan ini sebagai sebuah pengalaman yang berharga.

Simulasi percakapan antara pegawai dan pengunjung dalam Bahasa Inggris merupakan target pelatihan. Peserta mulai mampu mendeskripsikan tentang buah naga walaupun masih banyak kesalahan.

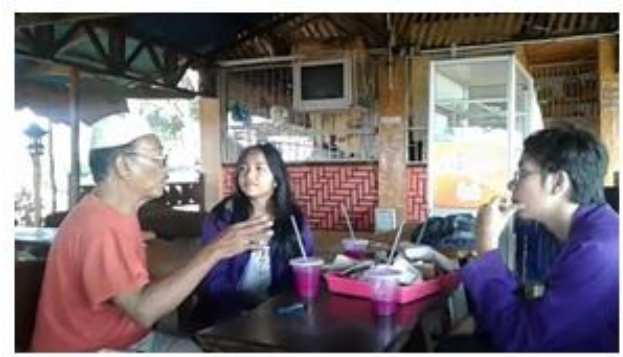

Gambar 6. Kegiatan Pelatihan Informal English Conversation

Sebelum kegiatan pelatihan, tim pengabdi melakukan simulasi dengan satu pegawai. Pegawai belum percaya diri karena belum terbiasa sehingga merasa canggung dan gugup. Pegawai menggunakan kalimat-kalimat pendek saat simulasi. Dapat disimpulkan bahwa setiap individu menghadapi rasa canggung dan gugup ketika tidak memiliki cukup pengetahuan untuk disampaikan. 


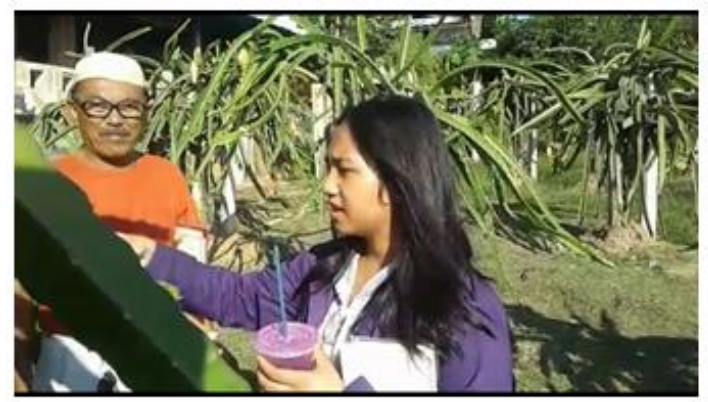

Gambar 7. Simulasi Percakapan di Perkebunan Buah Naga

Menutupi pelatihan ini, tim pengabdi membagikan materi pembelajaran. Diharapkan pegawai bisa belajar mandiri untuk melanjutkan atau mengulang materi pelatihan sehingga pegawai secara aktif dapat melayani pengunjung asing dengan Bahasa Inggris.

Kesinambungan usaha agrowisata perkebunan buah naga tidak lepas dari jumlah pengunjung yang datang. Semakin banyak wisatawan yang datang akan semakin memajukan usaha agrowisata di sekitarnya sebagai imbasnya. Oleh sebab itu para pegawai harus menjaga setiap kata dan perbuatan sehingga tidak menyinggung perasaan tamu-tamu yang datang ke daerah agrowisata.

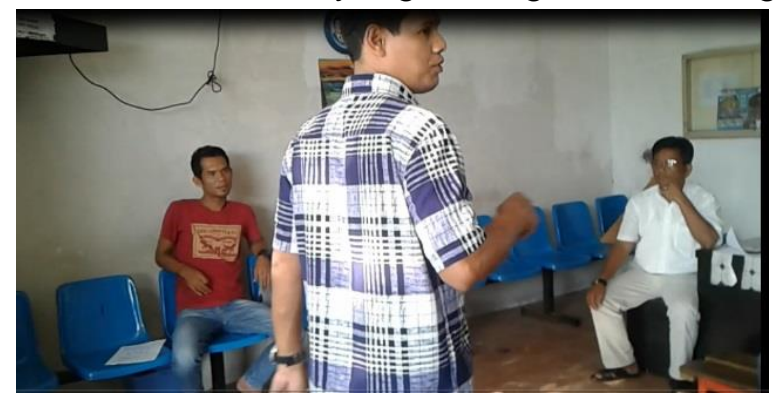

Gambar 8. Simulasi Percakapan di Kafe Zore

Pulau Batam yang dekat dengan Malaysia dan Singapura merupakan tempat bersinggahnya penduduk Singapura dan Malaysia untuk sekedar berbelanja dan menikmati keindahan kota Batam. Penduduk Singapura dan Malaysia yang menggunakan bahasa Inggris ingin dilayani dengan baik. Tidak hanya mereka, banyak juga wisatawan asing yang berkunjung ke Batam dari Amerika, Eropa, Australia dan lainnya, di samping ingin melihat keindahan alamnya mereka datang juga untuk melihat yang tidak ada di negara mereka seperti buah naga.

Keterampilan yang sudah dimiliki dipadukan dengan kemampuan kerja sama para peserta akan berdampak efektif dalam memberikan informasi serta mendukung program pemerintah (Siregar et al., 2019). Dengan profesi yang sama akan memudahkan berkomunikasi antar peserta dan mudah bekerja sama untuk tercapainya tujuan memiliki keterampilan berkomunikasi yang akan mendukung profesi dan program pemerintah Kota Batam.

\section{KESIMPULAN}

Agrowisata atau agroturisme adalah kegiatan kepariwisataan yang memanfaatkan usaha pertanian atau perkebunan sebagai objek wisata bertujuan memperluas pengetahuan, pengalaman, dan rekreasi (Utama \& Junaedi, 2010). 
Pemerintah Kota Batam menggalakkan industri pariwisata dengan salah satunya memperkenalkan agrowisata. Dan bahasa adalah media dalam memperkenalkan agrowisata di Pulau Batam terutama Bahasa Inggris.

Bahasa merupakan media komunikasi dalam bertukar ide dan informasi. Menggunakan bahasa yang benar akan berdampak baik terhadap pesan yang diterima. Yang sangat penting bagi pembicara (speaker) dalam menyampaikan pesan kepada pendengar (hearer) adalah makna pesan yang tersampaikan dan dimengerti sehingga dapat dilaksanakan. Menyampaikan pesan yang dapat dimengerti tidaklah mudah. Pemilihan kata-kata yang disusun dengan benar dalam ujaran (utterance) haruslah tepat dan jelas. Pada Bahasa Inggris, penyusunan kalimat haruslah disesuaikan dengan waktu pada saat kegiatan dilakukan. Pembentukan kalimat tidak sesuai dengan waktu akan berakibat salah dalam mengartikan kalimatnya.

(Brown, 2007) mengatakan bahwa kemampuan dalam berbahasa asing adalah yang utama, dan kemampuan berbicara adalah integrasi dari pengucapan, struktur, dan kosakata. Dan faktor-faktor ini yang menjadikan bahasa asing sebagai pembelajaran yang sulit bagi pelajar.

Pegawai Kafe Zore dan perkebunan buah naga yang tidak memiliki kemampuan Bahasa Inggris, haruslah diberi pelatihan Bahasa Inggris walaupun cukup sulit, tetapi dampak positifnya adalah komunikasi yang terjadi antara pegawai dan tamu atau pengunjung berjalan dengan baik, dan hubungan berkesinambunagn pegawai perkebunan dan pengunjung atau tamu dapat berjalan dengan baik di kemudian hari.

Walaupun tiga pertemuan masih dirasa kurang tetapi pelatihan ini cukup memberi dampak positif dalam mengasah kemampuan berbahasa Inggris pegawai. Pelatihan dengan penjadwalan waktu yang tepat cukup ampuh dalam memecahkan masalah pegawai berbahasa Inggris. Pelatihan praktik pengucapan, penguasaan kosakata, pembentukan kalimat sederhana dalam bentuk positif, negatif and pertanyaan, dan latihan percakapan Bahasa Inggris yang mengarah ke topik-topik tertentu seperti mengungkapkan maaf, pengulangan, penolakan, terima kasih dan lainnya akan sangat membantu para pegawai untuk bisa berbahasa Inggris.

\section{SARAN}

Mengingat akan pentingnya Bahasa Inggris dalam memperkenalkan buah naga sebagai kekayaan flora pulau Batam, perlu diadakannnya aksi nyata yang mendukung hal ini seperti pelatihan Bahasa Inggris yang intens dilakukan pada kelompok pengelola agrowisata. Di samping itu pengelola harus berkomitmen dalam melakukan pelatihan kepada pegawai di saat-saat senggang melaksanakan pekerjaan sebagai pekerja perkebunan. Komitmen yang kuat akan memperlancar kegiatan pelatihan. Tidak hanya bagi pegawai ataupun pengelola, pengabdi harus menunjukkan sikap yang mendukung pentingnya Bahasa Inggris pada saat sekarang dan semangat dalam melaksakana tugas yang diemban serta tak henti-hentinya memberikan semangat belajar kepada peserta pelatihan.

\section{DAFTAR PUSTAKA}

Ambalegin, A., Arianto, T., \& Azharman, Z. (2019). Kampung Tua Nongsa sebagai tujuan wisata berbasis kearifan lokal budaya Melayu Batam. Dinamisia, Jurnal Pengabdian Kepada Masyarakat, 3(Special Issue), 67-75. 
https://doi.org/DOI: https://doi.org/10.31849/dinamisia.v3i2.2863

Ambalegin, \& Suhardianto. (2020). Meningkatkan pendapatan supir taksi pelabuhan internasional Batam Centre melalui keterampilan berbahasa Inggris. JPPM (Jurnal Pengabdian Dan Pemberdayaan Masyarakat) LPIP Universitas Muhammadiyah Purwokerto, 4(1), 125-132.

Ambalegin, Suhardianto, \& Kaprawi, N. (2017). Obstacles facing learners in speaking English: Non-English teacher's perspective, Putra Batam School. Obstacles Facing Learners in Speaking English: Non-English Teacher's Perspective, Putra Batam School., 25(S), p 119-127.

Amna, S., Gusta, W., \& Primawati, Y. (2021). Meningkatkan kemampuan speaking dan writing Bahasa Inggris melalui kompetisi spelling bee. Jurdimas (Jurnal Pengabdian Kepada Masyarakat) Royal, 4(2), 157-164. https://doi.org/https://doi.org/10.33330/jurdimas.v4i2.974

Andidi, N. (2014). Pengorganisasian komunitas dalam pengembangan agrowisata di desa wisata studi kasus: Desa Wisata Kembangarum, Kabupaten Sleman. Jurnal Perencanaan Wilayah Dan Kota ITB, 24(3), 173184.

Brown, H. D. (2007). Teaching by principles: An interactive approach to langauge pedagogy (3rd ed.). Pearson Longman.

Budiarti, T., Suwarto, \& Muflikhati, I. (2013). Pengembangan agrowisata berbasis masyarakat pada usahatani terpadu guna meningkatkan kesejahteraan petani dan keberlanjutan sistem pertanian. Jurnal IImu Pertanian Indonesia (JIPI) IPB, 18(3), 200-207.

Crystal, D. (2003). English as a global language (Second Edi). Cambridge University Press.

Evyanto, W., \& Mubarak, Z. H. (2020). Pembinaan Percakapan Bahasa Inggris Bagi Masyarakat Perumahan Griya Batu Aji Asri Batam. Puan Indonesia, 1(2), 89-95. https://doi.org/10.37296/about.v1i2.14

Kachru, B. B., Kachru, Y., \& Nelson, C. L. (2006). The handbook of world Englishes (first edit). Blacwell Publishing Ltd.

Mustafidah, H., \& Harjono. (2019). Implementasi program QUEST untuk menganalisis butir soal bagi guru-guru SMP Muhammadiyah 2 Karangwelas. Jurnal Pengabdian Dan Pemberdayaan, LPIP UMP, 3(2), 321-328. https://doi.org/10.30595/jppm.v3i2.3378

Nugraha, A. R., Purbawasari, S., Zubair, F., \& Novianti, E. (2019). Pemberdayaan masyarakat melalui pelatihan komunikasi efektif berbasis potensi wisata dan kearifan lokal. Jurnal Pengabdian Dan Pemberdayaan Masyarakat, LPIP UMP, 3(1), 123-132.

Siregar, J. H., Anwar, C., \& Sangaji, M. (2019). Pelatihan pengelolaan aplikasi sistem informasi bagi warga kelurahan Sawah Baru, Tangerang Selatan. Jurnal Pengabdian Dan Pemberdayaan Masyarakat, LPIP UMP, 3(2), 343350. https://doi.org/10.30595/jppm.v3i2.4167

Utama, I. G. B. R., \& Junaedi, I. W. R. (2010). Agrowisata sebagai pariwisata alternatif Indonesia. Pendidikan Deepublish. 